\title{
Green Logistics in the Context of Sustainable Development in Small and Medium Enterprises
}

\section{Zelena logistika u kontekstu održivog razvitka u malim i srednjim pogonima}

\author{
Preliminary paper • Prethodno priopćenje \\ Received-prispjelo: 24. 3. 2016. \\ Accepted-prihvaćeno: 15. 11. 2016. \\ UDK: $630 * 79$ \\ doi:10.5552/drind.2017.1620
}

\begin{abstract}
Forestry and wood-processing industry are sectors based on renewable ecological natural resources of wood raw material. Wood mass processing should be based on sustainable development, which involves the economic and social development based on environment preservation. Green logistics, which leads to change in creating the product value, characterizes different possibilities to measure and minimize the ecological impact of logistics activities and puts emphasis on sustainable ecological orientation, is closely related to sustainable development. The aim of this article is to investigate the issue of green logistics of forestry and wood processing in small and medium enterprises in Slovakia. To reach this goal, an empirical research was carried out, the objective of which was to determine the level of understanding, as well as the implementation of green logistics activities, and to identify its potential for future implementation in small and medium enterprises in selected branches. The research has revealed that as many as $28.8 \%$ of enterprises claim not to have had any experience with green logistics within their enterprise. The greatest barrier for the implementation of green logistics appears to be the high input costs, which was confirmed by $62 \%$ of the enterprises. On the basis of the research results, a model of implementation of green logistics concept in Slovak small and medium forestry and wood-processing enterprises has been proposed, as an element of sustainable development.
\end{abstract}

Keywords: green logistics, sustainable development, small and medium enterprises (SMEs), forestry, wood processing, model

SAŽETAK • Šumarstvo i drvoprerađivačka industrija u Slovačkoj sektori su koji se temelje na obnovljivim, ekološkim, prirodnim resursima, odnosno na drvu kao osnovnoj sirovini. Prerada drvne mase trebala bi biti osnova održivog razvoja, što podrazumijeva ekonomski i socijalni razvoj utemeljen na očuvanju okoliša. Zelenu logistiku, koja donosi promjene u određivanju vrijednosti proizvoda, karakteriziraju različite mogućnosti mjerenja i smanjenja utjecaja logističkih aktivnosti na ekološki sustav, pri čemu je naglasak na održivoj ekološkoj orijentaciji, tijesno povezanoj s održivim razvojem. Istraživanje opisano u radu odnosi se na aspekte zaštite okoliša u malim i srednjim poduzećima za šumarstvo i preradu drva u Slovačkoj u kontekstu održivog razvoja i zelene logistike. Kako bi se ostvario glavni cilj istraživanja, provedeno je iskustveno istraživanje radi određivanja razine razumijevanja i implementacije aktivnosti zelene logistike te mogućnosti njezine buduće implementacije. Istraživanje

\footnotetext{
${ }^{1}$ Authors are doctors of science and associate professor at the Faculty of Economics, Matej Bel University in Banská Bystrica, Slovakia. ${ }^{2}$ Authors are associate professor and doctor of science at the Faculty of Wood Science and Technology, Technical University in Zvolen, Slovakia. ${ }^{3}$ The author is a PhD student at the University of Zagreb, Faculty of Forestry, Zagreb, Croatia.

${ }^{1}$ Autorice su doktorice znanosti i izvanredna profesorica Ekonomskog fakulteta Sveučilišta Matej Bel u Banskoj Bistrici, Slovačka. ${ }^{2}$ Autorice su izvanredna profesorica i doktorica znanosti Drvarskog fakulteta Tehničkog sveučilišta u Zvolenu, Slovačka. ${ }^{3}$ Autor je student doktorskog studija na Šumarskom fakultetu Sveučilišta u Zagrebu, Hrvatska.
} 
je pokazalo da $28,8 \%$ poduzeća u svom dosadašnjem radu nije imalo nikakvih iskustava sa zelenom logistikom. Najveću prepreku uvođenju zelene logistike čine visoki troškovi implementacije, što je potvrdilo 62 \% anketiranih poduzeća. Na osnovi rezultata istraživanja predložene su nove mogućnosti razvoja koncepta zelene logistike u slovačkim malim i srednjim pogonima u šumarstvu i drvoprerađivačkoj industriji kao dijela održivog razvoja poduzeća.

Ključne riječi: zelena logistika, održivi razvoj, mala i srednja poduzeća (SMEs), šumarstvo, drvoprerađivačka poduzeća, model

\section{INTRODUCTION}

\section{UVOD}

People's concern for environmental issues and sustainable development has been rising around the world and, therefore, businesses are pushed into taking responsibility for their products and services (Benčiková, 2013). Within this context, logistics in an enterprise should represent an effort to synchronize, coordinate, and optimize the flow of information and materials, in order to satisfy the needs of customers at an adequate cost and the lowest possible negative impact of corporate activities on the environment. The relation between the logistics processes and the ecological objectives forms the basis of green logistics (Nováková and Kusý, 2010).

Out of a number of authors (Hu and Hsu, 2003; Bjorklund et al., 2012; Brandenburg and Rebs, 2015; Tognetti et al., 2015), the most relevant opinions related to green logistics are presented by Lun et al. (2015), who defined it as a study of the impact on the environment, with the aim to measure and minimize the ecological impact of logistics activities.

Green logistics can be divided into four basic subsystems - green procurement logistics, green production logistics, green distribution logistics, and reverse logistics. In an enterprise, green procurement logistics is focused on the market orientation (market research, choosing the right suppliers, cooperating with partners in order to achieve environmental objectives, etc.), as well as on the orientation on physical tasks, i.e. those related to the flow of materials and products. Green production logistics is a sum of logistics tasks and measures needed to prepare and carry out the production process. It includes such activities that are connected with the flow of information, raw and other materials, reducing the amount of packaging material, and utilizing the renewable sources of energy. Green distribution logistics is a set of operations, which enable the goods or services to be shipped from the point of production to the customer, at the right amount, quality, location, time, and price. These are e.g. using electronic invoicing, loading the goods, optimizing the transportation routes, choosing ecological ways of transportation, but also lowering the $\mathrm{CO}_{2}$ emissions. Out of all logistics activities, distribution is the one that is most subject to various accidental influences, which requires a flexible structure so as to effectively respond to these influences (Sheu et al., 2005). Reverse logistics can be defined as a process of repeated acquiring of recyclable and renewable material, waste and reprocessed items from the point of consumption, as well as their use for repairs, readjustments, disposal, or storage (Gunasekaran and Spalanzani, 2012). This is mainly waste separation and recycling.

European markets, the Slovak economy is directly dependent on, require development of fields of industry, which have a certain specific position in the market (Bikár and Kmet'ko, 2015). Within the framework of the Slovak economy, this position is undoubtedly held by wood processing and forestry, which is the result of their comparative advantages. Wood processing and forestry of the Slovak Republic are relatively independent of the supply of raw material, and they can always show active balance of the foreign market. Wood processing and forestry, considering the positive state of raw material, good geographical location, and the acceptable energetic demand of wood processing, represent an important part of the Slovak national economy, and suggest good conditions for further development of small and medium enterprises (Sedliačiková et al., 2016).

One of the ways how to increase the productivity of the wood processing and forestry industry and enable the increase of export of our production (mainly in wood processing and forestry), is building small and medium enterprises operating in the field of wood processing and forestry via effective allocation of investment costs into production programs, which will increase the utilization of production capacities, lower the material and energetic demands, and enable knowhow in the field of environmental management of small and medium enterprises.

Small and medium enterprises (SMEs) are a crucial part of economic potential in most countries of the world, and this is not different in the Slovak Republic (Lesáková, 2012). A clear and explicit definition of terms "small" and "medium" does not exist. Approaches to defining SMEs are, therefore, different from author to author (Vavrová, 2014; Nováková, 2003; Ojurović at al., 2013). Small and medium-sized enterprises (SMEs) represent $99.8 \%$ of all businesses in the EU. Defining a SME is essential, as the access to finance and the EU support programs are targeted specifically at these enterprises. Small and medium-sized enterprises are defined in the European Commission Recommendation 2003/361. The main factors determining whether an enterprise is a SME are: staff headcount, and total turnover or balance sheet. According to the EC recommendation, SMEs represent those enterprises in which the staff headcount is less than 250, whose annual turnover does not exceed 50 million Euros, and/or total balance sheet does not exceed 43 million Euros. 
Current theoretical knowledge and practical experience of wood processing and forestry SMEs in Slovakia were investigated using a questionnaire to evaluate their perception of how the activities of green logistics can contribute to their operations. The results provided reliable feedback of the level of application of green logistics activities. The main objective of the research was to suggest an algorithm of implementation of green logistics activities into wood processing and forestry SMEs in Slovakia, based on the results of analysis of the implementation of the chosen green activities, as well as the obstacles to implementation of the 'green practice'.

This research, which is based on a random sample of wood processing and forestry SMEs, reports on green logistics activities, and focuses on the current state in the awareness as well as the use of green logistics and its potential in improving processes in enterprises.

\section{RESEARCH METHOD}

\section{METODA ISTRAŽIVANJA}

The research has been conducted in two phases. In the first phase, in 2014, the researchers conducted a secondary research aimed at the analysis of the domestic and foreign literature in order to compare the opinions of different authors concerning the given problem, as well as to develop theoretical foundations for the questionnaire. The second phase, carried out in the second half of 2014, was based on a primary research, which was done through the questioning method - a questionnaire. The main objective of the research was to find out how small and medium enterprises in wood processing and forestry industry in Slovakia perceive the activities of green logistics. To verify the assumptions, the following methods and tools were used: method of inference statistics (Chi-square test, the Friedman test, and the Wilcoxon test), Pareto analysis as a tool of decision making, methods of descriptive statistics (relative frequency, cumulative relative frequency, as methods of distribution description) and data visualization (graphs, frequency tables). The representativeness of the sample was tested using the Chi-square test, by the chosen variables. Friedman test was used to analyze the significance of differences between related samples, and the Wilcoxon test assessed the agreement between the responses in two different samples. Pareto analysis was used to identify the key activities of green logistics, and the key barriers of its implementation.

\subsection{Data collection}

\subsection{Prikupljanje podataka}

The data collected was specifically designed to determine the current level of use of green logistics activities in wood processing and forestry SMEs in Slovakia. The questionnaire was designed in two parts: Part A - 4 questions: Type of enterprise (A1 - A3)

Part B - 5 questions: Green logistics (B1 - B5)

Part A was aimed at determining the characteristics of the enterprise size (small or medium), form of the enterprise (trade, production) and the market the enterprises operate in (local, regional, national, European, and global). Part B focused on identifying the state and the level of implementation of green logistics activities in selected wood processing and forestry SMEs in Slovakia, as well as on identifying the potential interest of the selected wood processing and forestry SMEs concerning the topic of this paper.

\subsection{Sample size \\ 2.2. Veličina uzorka}

The questionnaire was distributed among 500 randomly selected wood processing and forestry industry SMEs in Slovakia, out of which 309 questionnaires have been filled in and returned. For the purposes of this research, 248 correctly and fully filled in questionnaires have been used to evaluate the results. The representativeness of the sample according to the selected attribute (size of the enterprise, determined on basis of the number of employees) has been proved, as the $p$ value was higher than the level of significance $(\alpha=$ $0.05)$. Overall, 240 small and 8 medium enterprises have participated in the research, 132 small and 3 medium enterprises being in the field of wood processing. The forestry industry was represented by 108 small and 5 medium enterprises. Of this number, $45 \%$ was trade and $55 \%$ was the production SMEs. The turnover in most enterprises (37.2\%) was between 10,001-100,000 Euros, while these enterprises mostly operate on regional markets $(28 \%)$. Local market is represented by $24 \%$ of respondents, national market by $25.2 \%$, European by $19.2 \%$ and the global market by $3.6 \%$ of the analyzed enterprises.

\subsection{Methods of research analysis}

2.3. Metode analize rezultata istraživanja

The survey data were analyzed by descriptive methods, graphic visualization, and statistical analysis. Question B1, aimed at determining the agreement, was evaluated on the basis of the Likert scale, where 1 meant the weakest agreement, and 7 meant the strongest agreement with the statement. Likert scale is not only used to determine the content of the attitude but also its approximate strength. The question was focused on the meaning that the term "green logistics" had for wood processing and forestry SMEs in Slovakia. In questions B2 and B3, the addressed enterprises were asked to select one option from the list. The questions were aimed at finding out if the implementation of green logistics is important for wood processing and forestry SMEs in Slovakia, and if the activities of green logistics are implemented in specific enterprises. The responses to the first three questions of Part B were evaluated by relative frequencies in frequency tables.

To evaluate the responses to questions B4 and B5, the authors have used the Friedman and Wilcoxon tests. Question B4 was aimed at finding out which activities of green logistics the enterprise plans to implement, while the respondents could select from 15 different activities. The enterprises had the following options: 1 - not planning anything, 2 - planning long-term, 3 - planning short-term, and 4 - already implementing. Question B5 
focused on what wood processing and forestry SMEs perceive as the greatest barriers to green logistics implementation. Respondents were asked to select three most preferred options on the given list.

Since questions B4 and B5 were structured as multiple-choice responses, the results were interpreted by relative frequencies as a percentage of responses and as a proportion of the addressed enterprises - percentage of cases. Considering the fact that these are ordinal variables, Friedman and Wilcoxon tests were used to verify the agreement of the levels of different dependent samples. The Friedman test is the non-parametric alternative to the one-way ANOVA test (Analysis of Variance) with repeated measures. It is used to test the differences between groups when the dependent variable being measured is ordinal. It can also be used for continuous data that has violated the assumptions necessary to run the one-way ANOVA with repeated measures (e.g. data that has marked deviations from normality). In case the hypothesis concerning the agreement of the levels of different dependent choices is denied, it is possible to compare the pairs of choices aiming at the identification of the significant differences between the levels of responses, i.e. to continue testing with the use of the Wilcoxon test. The Wilcoxon signed-rank test is the nonparametric test equivalent to the dependent t-test. As the Wilcoxon signed-rank test does not assume normality in the data, it can be used when this assumption has been violated and the use of the dependent t-test is inappropriate. It can be used to compare two sets of ordinal data. Pareto analysis has also been used as a statistical technique in decision making used for selecting a limited number of tasks that produce significant overall effect. This analysis uses the Pareto Principle (also known as the $80 / 20$ rule) meaning that by doing $20 \%$ of the work you can generate $80 \%$ of the benefit of doing the entire work. In terms of quality improvement, a large majority of problems $(80 \%)$ are produced by a few key causes $(20 \%)$. This is also known as the vital few and the trivial many. All statistical analysis and graphic presentations were done using the SPSS statistical program package.

\section{RESULTS AND DISCUSSION 3. REZULTATI ISTRAŽIVANJA I RASPRAVA}

\subsection{Results of empirical research}

3.1. Rezultati iskustvenog istraživanja

On the basis of descriptive statistics, it has been established that wood processing and forestry SMEs in Slovakia mostly agree with the statement that 'green logistics is an ecological way to transport materials and goods, and to use packaging which does not hurt the environment' (B1). As many as $42 \%$ of the questioned enterprises have responded that the implementation of green logistics is necessary for wood processing and forestry SMEs in Slovakia in order to remove or reduce the negative effects of business on the environment (B2). A very interesting finding is that $45.2 \%$ of the addressed enterprises do implement the activities of green logistics, but, on the other hand, this is not standardized within their corporate documents. Moreover, $28.8 \%$ of the enterprises claim that so far they have not had any experience with the activities of green logistics (B3).

Table 1 Friedman test, question B4

Tablica 1. Friedmanov test, pitanje B4

\begin{tabular}{|c|c|c|}
\hline \multicolumn{2}{|c|}{$\begin{array}{l}\text { Rank } \\
\text { Tvrdnja }\end{array}$} & \multirow{2}{*}{$\begin{array}{c}\text { Mean Rank } \\
\text { Srednja vrijednost } \\
6.81\end{array}$} \\
\hline B4a & - using alternative fuel / upotreba alternativnoga goriva & \\
\hline $\mathrm{B} 4 \mathrm{~b}$ & $\begin{array}{l}\text { - adjustment of vehicles to achieve lower consumption } \\
\text { prilagodba vozila radi smanjenja potrošnje }\end{array}$ & 8.15 \\
\hline B4c & - ecological style of driving / ekološki način vožnje & 10.01 \\
\hline B4d & $\begin{array}{l}\text { - use of ways of transport with low negative impact on the environment } \\
\text { način transporta s manjim negativnim učinkom na okoliš }\end{array}$ & 8.52 \\
\hline B4e & - optimizing the transport routes / optimiziranje transportnih putova & 10.99 \\
\hline B4f & $\begin{array}{l}\text { - making the loading of the transported goods more efficient } \\
\text { uspostava učinkovitijeg načina utovara proizvoda }\end{array}$ & 11.24 \\
\hline B4g & $\begin{array}{l}\text { - using sustainable sources of energy } \\
\text { iskorištavanje održivoga (obnovljivog) izvora energije }\end{array}$ & 7.66 \\
\hline B4h & $\begin{array}{l}\text { - gathering information about energy consumption and } \mathrm{CO}_{2} \\
\text { prikupljanje podataka o utrošku energije i ispuštenom } \mathrm{CO}_{2}\end{array}$ & 6.95 \\
\hline B4i & $\begin{array}{l}\text { - reduction of the amount of packaging material } \\
\text { smanjenje količine materijala za pakiranje }\end{array}$ & 10.27 \\
\hline $\mathrm{B} 4 \mathrm{j}$ & $\begin{array}{l}\text { - certification in the field of ecology and environment } \\
\text { posjedovanje certifikata s područja ekologije i zaštite okoliša }\end{array}$ & 6.18 \\
\hline B4k & $\begin{array}{l}\text { - implementing lowering the } \mathrm{CO}_{2} \text { emissions into primary corporate objectives } \\
\text { politika smanjenja emisija } \mathrm{CO}_{2} \text { kao jednoga od primarnih ciljeva poduzeća }\end{array}$ & 6.32 \\
\hline B41 & $\begin{array}{l}\text { - cooperation with stakeholders in order to achieve the environmental goals } \\
\text { suradnja s vlasnicima radi postizanja ekoloških ciljeva }\end{array}$ & 6.75 \\
\hline B4m & $\begin{array}{l}\text { - cooperation with customers in order to achieve the environmental goals } \\
\text { suradnja s korisnicima (kupcima) radi postizanja ekoloških ciljeva }\end{array}$ & 6.92 \\
\hline B4n & - environmental education for employees / izobrazba uposlenih o zaštiti okoliša & 7.31 \\
\hline B4o & - environmental education for customers / izobrazba korisnika (kupaca) o zaštiti okoliša & 5.91 \\
\hline
\end{tabular}


Table 2 Friedman test, question B4

Tablica 2. Friedmanov test, pitanje B4

\begin{tabular}{|l|c|}
\hline $\begin{array}{l}\text { Test Statistics - Friedman Test } \\
\text { Statističke vrijednosti testa - Friedmanov test }\end{array}$ \\
\hline$N$ & 250 \\
\hline Chi-Square $/ \chi^{2}$ & 840.327 \\
\hline$d f$ & 14 \\
\hline Asymp. Sig. & 0.000 \\
\hline
\end{tabular}

Application of the Friedman test (Tables 1 and 2) has confirmed that the given activities of green logistics are not of the same importance to the enterprises with regard to the time frame of planning their implementation $(p$-value $=0.0)$. Based on the data collected in the primary research, the Wilcoxon sign rank test was used to establish which activities are not of the same importance. On the basis of the Friedman and the Wilcoxon tests, it is possible to claim that in the field of green logistics, wood processing and forestry SMEs in Slovakia put most emphasis on optimizing the transport routes (B4e) as well as making the loading of the transported goods more efficient (B4f).

The activities of green logistics, such as the use of alternative fuel in transportation (B4a), use of sustainable sources of energy (B4g), gathering information about energy consumption and $\mathrm{CO}_{2}$ emissions (B4h), certification in the field of ecology and environment (B4j), cooperation with partners and customers in order to achieve the environmental goals (B4m), and environmental education of the employees (B4n) and customers (B4o), show the lowest planning activity. This finding has proved that the enterprises only provide some of the activities of green logistics and do not perceive it as a tool that can help them achieve competitive advantage and thus ensure their stable position in the market.

This has also been proved by Pareto analysis (Fig. 1), on the basis of which the key activities of green logistics in wood processing and forestry SMEs in Slovakia have been identified. Out of 15 suggested activities, those that the enterprises plan to implement in a short-term period of time, or are already implementing, were identified 1,020 times. As it is clear from the Lorenzo curve (curve of cumulative relative frequencies expressed as a percentage), according to wood processing and forestry SMEs in Slovakia, 60.88 $\%$ responses related to activities which the enterprises are either planning to implement in a short time or are already using, concern the following activities of green logistics: making the loading of the transported goods more efficient (B4f), optimizing the transport routes (B4e), reduction of the amount of packaging material (B4i), ecological style of driving (B4c) and use of ways of transport with low negative impact on the environment (B4d). Making the loading of the transported goods more efficient (B4f) was chosen by $77 \%$ of the enterprises (percentage of cases) as the activity which they are either planning to implement in a short-term period of time or are already implementing.

On the other hand, only $21.08 \%$ of the addressed enterprises are planning to educate, or are already educating their employees (B4n). By selecting and planning education of the employees properly, it is possible to ensure implementation of processes of green logistics, such as: choice of environmentally suitable suppliers, effective allocation of the production equipment in the enterprise, ecological style of driving, gathering information about emissions and energy consumption, reduction of the amount of packaging material, and cooperation with customers. These are often financially demanding and can save the enterprise the costs related to transportation, manipulation with the material, production, and last, but not least, loss of a customer.

Evaluation of the question related to finding out the barriers to implement the processes of green logistics (B5) was also very important. Friedman test (Tables 3-4)

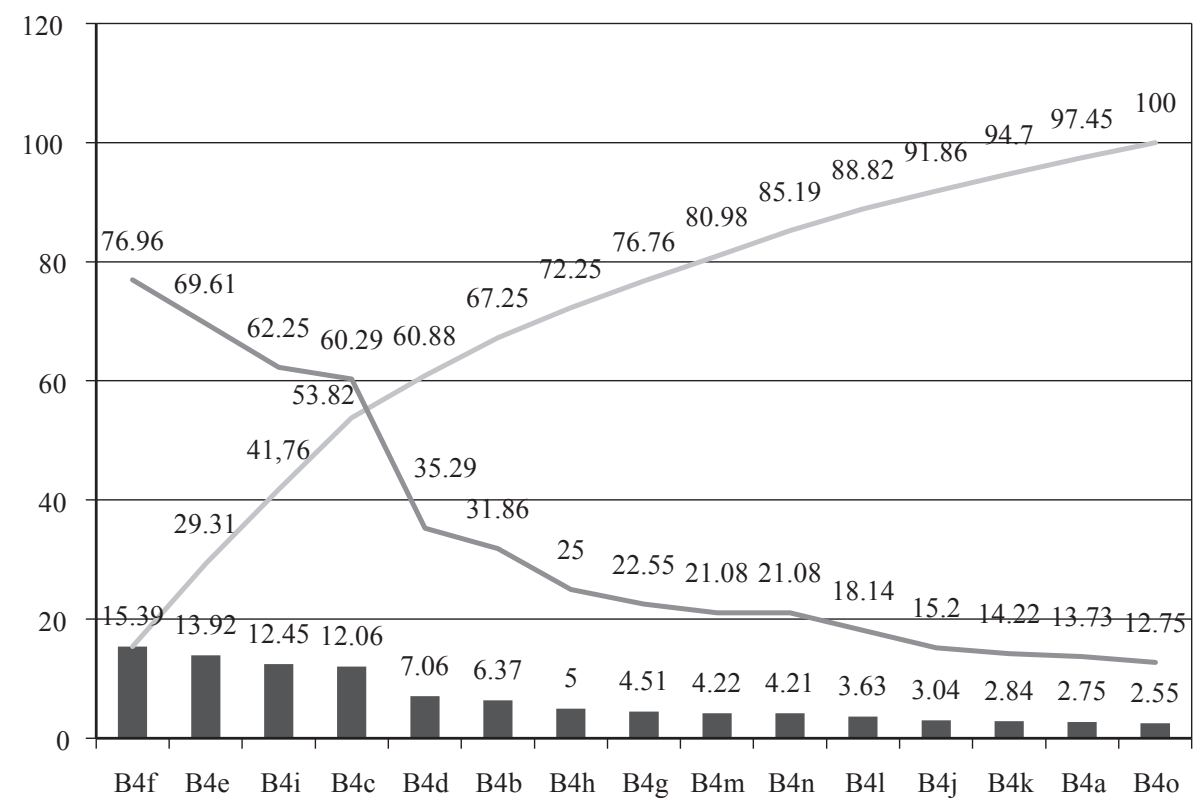

\begin{tabular}{|l|}
\hline Relative \\
frequency of \\
responses \\
Relativna \\
frekvencija \\
odgovora \\
Cumulative \\
relative \\
frequency of \\
responses \\
Kumulativna \\
relativna \\
frekvencija \\
odgovora \\
Percentage of \\
cases \\
Postotni udio \\
slučajeva
\end{tabular}

Figure 1 Pareto analysis, question B4

Slika 1. Paretova analiza, pitanje B4 
Table 3 Friedman test, question B5

Tablica 3. Friedmanov test, pitanje B5

\begin{tabular}{|l|l|c|}
\hline \multicolumn{2}{|c|}{$\begin{array}{c}\text { Rank } \\
\text { Tvrdnja }\end{array}$} & $\begin{array}{c}\text { Mean Rank } \\
\text { Srednja vrijednost }\end{array}$ \\
\hline B5a & - high input costs / visoki troškovi uvođenja zelene logistike & 8.80 \\
\hline B5b & - uncertain return on the invested sources / nesigurnost povrata uloženih sredstava & 7.53 \\
\hline B5c & - high operational costs / visoki operativni troškovi & 6.45 \\
\hline B5d & - insufficient financial resources / nedostatak financijskih sredstava & 7.72 \\
\hline B5e & - lack of qualified workforce / nedostatak kvalificirane radne snage & 6.01 \\
\hline B5f & - insufficient knowledge of green logistics / nedovoljno znanje o zelenoj logistici & 6.85 \\
\hline B5g & - lack of interest of customers / nedostatna zainteresiranost korisnika (kupaca) & 5.05 \\
\hline B5h & - insufficient support from the government / nedostatna potpora vlasti & 7.77 \\
\hline B5i & $\begin{array}{l}\text { - weak support of transportation companies and distributors } \\
\text { slaba potpora transportnih poduzeća i distributera }\end{array}$ & 5.53 \\
\hline B5j & - lack of interest in SMEs / nedostatna zainteresiranost malih i srednjih poduzeća & 5.89 \\
\hline B5k & $\begin{array}{l}\text { - limited access to technologies lowering the negative impact on the environment } \\
\text { ograničen pristup tehnologijama za smanjenje negativnog utjecaja na okoliš }\end{array}$ & 5.34 \\
\hline B51 & $\begin{array}{l}\text { - lack of opportunities to educate employees in the field of environment } \\
\text { nemogućnost izobrazbe uposlenih o zaštiti okoliša }\end{array}$ & 5.05 \\
\hline
\end{tabular}

Table 4 Friedman test, question B5

Tablica 4. Friedmanov test, pitanje B5

\begin{tabular}{|l|c|}
\hline $\begin{array}{l}\text { Test Statistics - Friedman Test } \\
\text { Statističke vrijednosti testa - Friedmanov test }\end{array}$ \\
\hline$N$ & 250 \\
\hline Chi-Square / $\chi^{2}$ & 581.491 \\
\hline$d f$ & 11 \\
\hline Asymp. Sig. & 0.000 \\
\hline
\end{tabular}

has proved that small and medium enterprises do not consider the barriers mentioned in the questionnaire to be of the same importance ( $p$-value $=0)$. Wilcoxon test has proved $(p$-value $=0$ ) that for the enterprises, the greatest obstacle to implement the processes of green logistics is the high input costs (B5a). The second biggest barrier appears to be the lack of support from the government/state (B5h), uncertain return on the investments (B5b), and lack of financial resources (B5d). On the other hand, the smallest barrier, as perceived by the respondents, proves to be the lack of interest from the customers (B5g) and insufficient possibilities to educate the employees in the field of environment (B51).

Pareto analysis (Fig. 2) has confirmed the results of the Friedman and the Wilcoxon tests. When evaluating question B5, the barriers of implementation of green logistics were assessed from the point of view of frequency in segmentation according to the individual Slovak SMEs. Subsequently, relative frequency and cumulative relative frequency of responses were calculated and expressed in percentage. It can be claimed that as many as $77.18 \%$ of the chosen barriers in implementing green logistics are represented by high input costs, (B5a), lack of support from the government (B5h), insufficient financial sources (B5d), uncertain return on investments (B5b), and insufficient knowledge of the problems of green logistics (B5f). Almost $60 \%$ of barriers, as identified by the enterprises, are

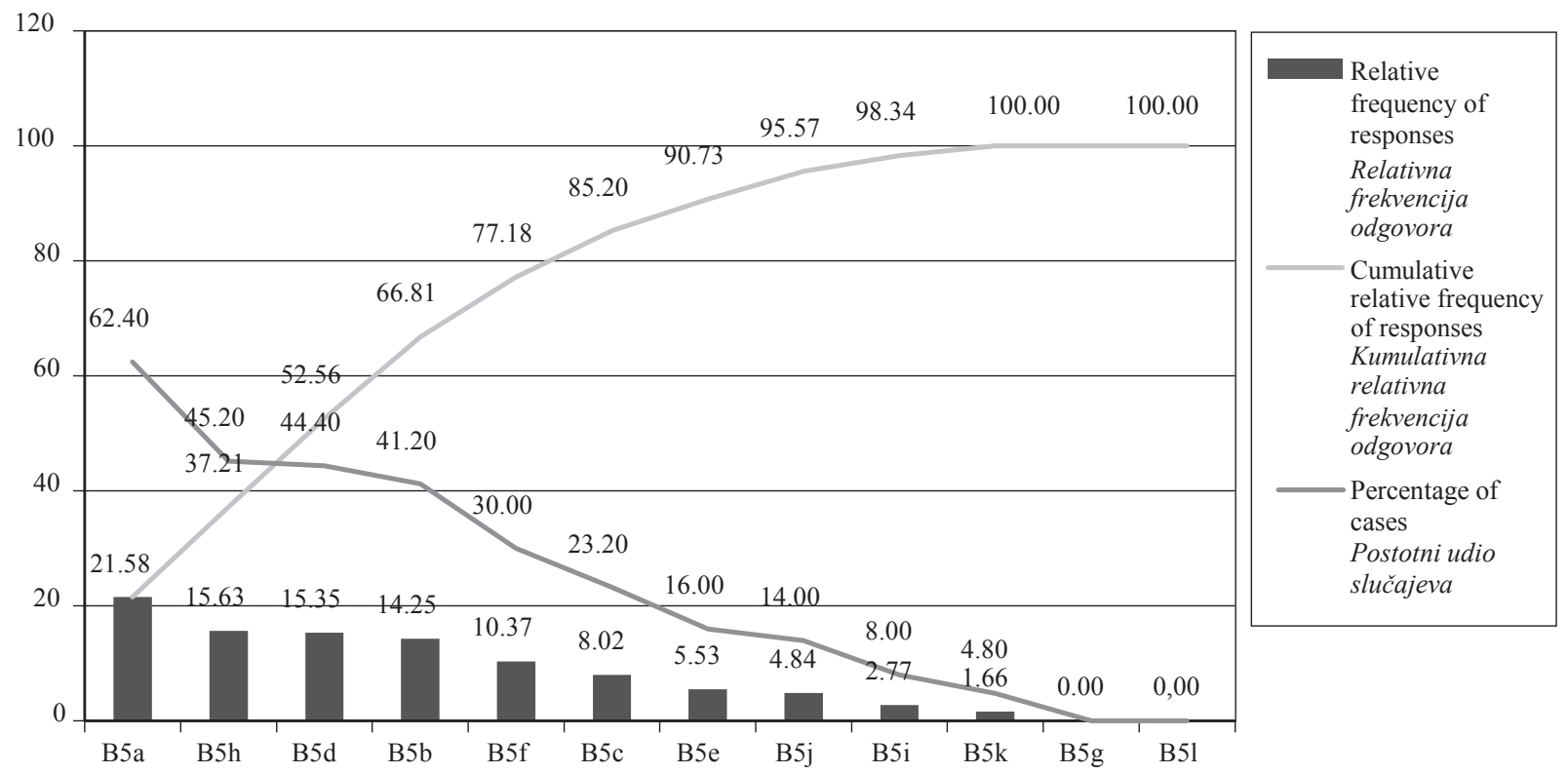

Figure 2 Pareto analysis, question B5

Slika 2. Paretova analiza, pitanje B5 
financial barriers, and $40 \%$ are non-financial. This has also been confirmed by $62.4 \%$ enterprises that have identified high input costs as the greatest barrier (B5a).

On the basis of the research results, it may be stated that wood processing and forestry SMEs in Slovakia are currently engaging only in a minimum number of activities of green logistics. Benčiková (2013) suggests that the trend in educating managers in Slovakia is to focus primarily on managerial and financial skills, rather than issues related to the psychological, cultural or environmental well-being of an enterprise. High input investment is considered as the biggest barrier by the respondents. At the same time, the enterprises do not plan to educate their employees in this field within a short-term period, which would in fact make the processes the employees are responsible for more effective. Activities of green logistics are often financially inexpensive, but the lack of interest in education in this field leads to ineffective performance of the processes in an enterprise and results in loss of financial resources, which could be invested in activities of green logistics. Creation, development, use and evaluation of knowledge is crucial for the enterprise to ensure its further development, as well as in terms of gaining and maintaining the competitive advantage (Minárová, 2014).

\subsection{Proposal of development of green logistics in wood processing and forestry SMEs}

3.2 Prijedlog razvoja zelene logistike u malim i srednjim poduzećima

Within the past few years, considerable pressure has been put on the wood processing and forestry SMEs to make them more involved in the initiatives of green logistics. When making their purchases, customers are more and more interested in the question if SMEs are providing their activities with regard to the environment (Lipušček et al., 2010).

At present, it is important to 'think green'. But conversely, the available resources of wood processing and forestry SMEs in Slovakia are limited. As a result of the lack of financing opportunities, wood processing and forestry SMEs depend on other capital sources such as bank loans or other alternative sources of finance. Current developments require new innovative approaches in entrepreneurship to be competitive (Sedliačiková et al., 2016). Not all activities of green logistics are financially demanding. The main goal of this research was to find out how SMEs in Slovakia approach the implementation of the initiatives of green logistics. On the basis of the research results, an algorithm of implementation of green logistics for Slovak wood processing and forestry SMEs was proposed (Table 5), which can help SMEs in putting emphasis on added environmental value (voluntary environmental activities exceeding the frame of the basic responsibilities mandated by the legislation). This not only offers higher environmental protection but also increases the competitive advantage of the enterprises.

The stakeholders and their requirements represent the foundation for implementing the initiatives of green logistics in wood processing and forestry SMEs.
The main barriers to implement the initiatives of green logistics are not only the financial and economic factors, but also the perception of stakeholders, who expect these initiatives on one hand, but on the other, they are not willing to pay for green initiatives. At the same time, their requirements in the given field are unclear and vague.

At present, the wood processing and forestry industries are facing numerous environmental issues and challenges. They are directly influenced by climate change, competition in obtaining the wood resources, changing consumer demands, increasing economic competition, and the growing complexity of production processes. Despite these problems, a great innovation opportunity for traditional forestry and wood sector that uses renewable natural resources in a sustainable and responsible way is to increase the quality and the level of finalizing the wood processing, as well as to increase the effectiveness of energy use of wood processing waste. By implementing the activities of green logistics, growing effectiveness of production can be achieved, and hence also the industry's sustainability. Wood processing and forestry represent not only an important part of a developing economy, but also of the whole society, with a new prospective direction based on biotechnologies. The use of wood as a renewable resource is of a great importance for the whole society, because: wood and wooden products sequester carbon and lower its volume in the atmosphere; wooden products are made in an energy-efficient production system, with lowest possible emissions when compared to other building materials; waste wood from the sawmills can be used to produce wood-based panels; and finally, wooden products may be reused, recycled, and in the end of their life cycle, they can be used as a source of bioenergy.

Based on the results of the empirical research, it can be concluded that there is no unified algorithm for the implementation of green logistics activities in Slovak wood processing and forestry SMEs. The model of algorithm for the implementation of green logistics activities proposed in this paper includes seven basic steps. The findings suggest that the implementation of this algorithm can help managers to define which green practices within their organization require more attention and which green practices may be given less attention. This ranking assists managers in allocating resources and financial investments appropriately. As Seroka-Stolka (2014), Farahani et al. (2010) and Neto et al. (2009) concluded that the generally rising attention that is paid to the greener solutions does not exclude logistics. It plays a very important role, as it is one of the main pollution sources and resource user. As reported by $\mathrm{Hu}$ and $\mathrm{Hsu}$ (2003) and Govindana et al. (2015), green supply chain management practices can create benefits to enterprises in the form of reduced waste, better resource use, economic advantages, and decrease in costs. Thus green supply chain management practices play an important role in undergoing sustainable development of enterprises and in improving social, environmental and economic benefits. The 
Table 5 Algorithm of implementation of activities of green logistics

Tablica 5. Algoritam uvođenja aktivnosti zelene logistike

\section{1. $\quad$ External analysis - stakeholder view}

Vanjska analiza - sa stajališta vlasnika

The goal of this step is to obtain information about the activities of green logistics, which are valuable for the given enterprise, from the stakeholders who can: / Cilj tog koraka jest prikupljanje informacija o aktivnostima zelene logistike važnima za poduzeće od vlasnika:

- provide information related to creating an action plan of improvement in the field of environment / koji daju informacije o pripremi plana za poboljšanja u području zaštite okoliša

- support the enforcement of the final decision / koji podržavaju provođenje završne odluke

- assist in determining the criteria and various solutions to individual alternatives of the action plan in environmental improvement / koji pomažu u određivanju kriterija i različitih rješenja do pojedinih varijanti akcijskog plana poboljšanja zaštite okoliša

- decide about the right choice and its implementation / koji odlučuju o pravom izboru i njegovoj implementaciji. Development of wood processing and forestry is based on the requirements of stakeholders and on sustainable use of wood resources. The main objective of this step is to obtain information on the needs of all stakeholders and focus the initiatives of green logistics towards satisfying such needs that are specific for the customer segment in the wood processing and forestry industry. At the same time, risks that are characteristic of this field of industry must be identified. / Razvoj u šumarstvu i preradi drva temelji se na zahtjevima vlasnika i održivom iskorištavanju drvnih resursa. Glavni cilj tog koraka jest prikupljanje informacija o potrebama svih vlasnika i usmjeravanje postupaka inicijative zelene logistike na zadovoljenje tih potreba, karakterističnih za šumarstvo i preradu drva. Istodobno se trebaju odrediti i svi rizici u tim industrijskim granama.

The right implementation of Step 1 leads to the removal of barriers B5 g, h, i. / Pravilna implementacija 1. koraka vodi uklanjanju barijera $B 5 \mathrm{~g}, h$, $i$.

2. Internal analysis - enterprise view Unutarnja analiza - sa stajališta poduzeća

It is the analysis of the SME's opportunities to provide new services in the environmental area, and thus differentiate from its competitors. The main goal of this step is the analysis of disposable resources of the enterprise. It is essential to create a new offer of green logistics activities for customers, from the point of view of the current situation in an enterprise.

In order to support the obligation of an enterprise to lower the impact of its corporate activities on the environment, the enterprises are encouraged to ensure an efficient cooperation between the individual departments and organize staff training related to ecological problems.

The right implementation of Step 2 leads to the removal of barriers B5 a, b, c, d, e, j.

Riječ je o analizi mogućnosti malih i srednjih poduzeća da pruže nove usluge u području zaštite okoliša i po tome budu različiti od konkurencije. Glavni cilj tog koraka jest analiza resursa što ih poduzeće ima na raspolaganju. Nužno je stvoriti novu ponudu aktivnosti zelene logistike prema kupcima, posebice sa stajališta trenutačne situacije u poduzeću. Kako bi se poduprle obveze poduzeća za snižavanje utjecaja njegovih aktivnosti na okoliš, predlaže se da poduzeća osiguraju dobru suradnju među pojedinim odjelima i organiziraju edukaciju osoblja vezanu za ekološke probleme. Pravilna implementacija 2. koraka vodi uklanjanju barijera B5 $a, b, c, d, e, j$.

3. Identification of opportunities - creating a new value system Identifikacija mogućnosti - stvaranje novog sustava vrednovanja

On the basis of findings from the internal and external audits and their comparison, SMEs will identify their strengths and weaknesses, and estimate potential environmental risks. The main aim of this step is to create an action plan of improvement in the environmental area, which includes the potential of development in initiatives of green logistics. These are activities, such as:

Na osnovi vanjske i unutarnje analize te njihove usporedbe, mala i srednja poduzeća identificirat će svoje prednosti $i$ slabosti te odrediti potencijalne rizike koje imaju za okoliš. Glavni cilj tog koraka jest priprema akcijskog plana poboljšanja u području zaštite okoliša koji će obuhvatiti mogući razvoj aktivnosti zelene logistike. To su aktivnosti poput: - employee training in the field of environment (e.g. ecological style of driving, etc.) - removes barriers B5 e, 1. / obrazovanja uposlenih o zaštiti okoliša (npr. o ekološkom načinu vožnje i sl.) - uklanjanje barijera B5 e, $l$ - careful management and monitoring of energy consumption and $\mathrm{CO}_{2}$ emissions - removes barriers $\mathrm{B} 5 \mathrm{~b}, \mathrm{c}, \mathrm{k}$. / briga menadžmenta i praćenje iskorištavanja energije i emisije $\mathrm{CO}_{2}$, uklanjanje barijera $\mathrm{B} 5 \mathrm{~b}, c, k$ - decrease in the material demands of production - removes barriers B5 c, d, g, k. / smanjenje upotrebe materijala $u$ proizvodnji, uklanjanje barijera B5 $c, d, g, k$

- choice of environmentally suitable suppliers - removes barriers B5 c, d. / odabir ekološki prihvatljivih dobavljača, uklanjanje barijera B5 $c, d$

- waste separation and recycling - removes barriers B5 c, d, g, k. / odvajanje otpada i recikliranje, uklanjanje barijera $B 5 c, d, g, k$

- optimizing the transportation routes - removes barriers B5 c, d, i. / optimiziranje transportnih putova, uklanjanje barijera $B 5 c, d, i$

- monitoring the use of vehicles (load, way of parking, maximum use of capacity) - removes barriers B5 c, d, i $/$ praćenje iskorištenosti vozila (utovara, načina parkiranja, maksimalnog korištenja kapaciteta), uklanjanje barijera $B 5 c, d, i$

- prevention program of vehicle maintenance in order to decrease the consumption and environmental pollution - removes barriers B5 a, c, d, k/ program prevencije u održavanju i uporabi vozila kako bi se smanjilo njihovo korištenje i onečišćenje okoliša, uklanjanje barijera $B 5 a, c, d, k$ 
Table 5 Algorithm of implementation of activities of green logistics

Tablica 5. Algoritam uvođenja aktivnosti zelene logistike

\begin{tabular}{|c|c|}
\hline & $\begin{array}{l}\text { - reduction in the amount of packaging material - removes barriers B5 b, c, d, g. / smanjenje količine materijala za } \\
\text { pakiranje, uklanjanje barijera B5 b, } c, d, g \\
\text { - decreasing water consumption by means of simple water recycling methods - removes barriers B5 a, b, c, d } \\
\text { smanjenje upotrebe vode i primjena jednostavnih metoda recikliranja, uklanjanje barijera B5 a, b, c, d } \\
\text { - energy-efficient production, use of renewable sources of energy - removes barriers B5 c, d, g, } \mathrm{k} \\
\text { energetski učinkovita proizvodnja, korištenje obnovljivih izvora energije, uklanjanje barijera B5 c, d, g, } k \\
\text { - purchasing environmentally efficient technologies - removes barriers B5 c, d, k } \\
\text { nabava ekološki učinkovite tehnologije, uklanjanje barijera B5 c, } d, k \\
\text { - digitalization (less paper in the offices) - removes barriers B5 c, d, g } \\
\text { digitalizacija (uz manje količine papira u uredima), uklanjanje barijera B5 c, d, g. }\end{array}$ \\
\hline \multirow[t]{2}{*}{4.} & $\begin{array}{l}\text { Development of human resources towards the environment } \\
\text { Razvoj ljudskih potencijala prema zaštiti okoliša }\end{array}$ \\
\hline & $\begin{array}{l}\text { The main objective is to ensure organization support and suitable human resources. It is essential to plan the training } \\
\text { and to educate the employees in order to increase their awareness of and knowledge in the field of green logistics. } \\
\text { The right implementation of Step } 4 \text { leads to the removal of barriers B5 e, f, } 1 \text {. } \\
\text { Glavni je cilj tog koraka osigurati potporu organizaciji i adekvatne ljudske potencijale. To je nužno pri planiranju } i \\
\text { obrazovanju uposlenika kako bi se povećala svijest i znanje o zelenoj logistici. } \\
\text { Pravilna implementacija 4. koraka vodi uklanjanju barijera B5 e, f, l. }\end{array}$ \\
\hline \multirow[t]{2}{*}{5.} & $\begin{array}{l}\text { Implementation of green logistics activities into an enterprise } \\
\text { Uvođenje aktivnosti zelene logistike u poduzeće }\end{array}$ \\
\hline & $\begin{array}{l}\text { The right implementation of Step } 5 \text { leads to the removal of barriers } \mathrm{B} 5 \mathrm{~b}, \mathrm{c}, \mathrm{e}, \mathrm{f}, \mathrm{g}, \mathrm{i}, \mathrm{j}, \mathrm{k}, \mathrm{l} \text {. } \\
\text { Pravilna implementacija 5. koraka vodi uklanjanju barijera } B 5 \mathrm{~b}, c, e, f, g, i, j, k, l .\end{array}$ \\
\hline \multirow[t]{2}{*}{6.} & $\begin{array}{l}\text { Evaluation of the environmental behavior of the enterprise } \\
\text { Vrednovanje odnosa poduzeća prema okolišu }\end{array}$ \\
\hline & $\begin{array}{l}\text { Based on the environmental norms of quality management, it was proposed to organize evaluation in these three areas: } \\
\text { Na osnovi normi za zaštitu okoliša u upravljanju kvalitetom, predlaže se vrednovanje triju područja: } \\
\text { - Management - described by indicators of managers' behavior (Management Performance Indicators MPI) } \\
\text { menadžmenta - opisivanje pokazatelja menadžerskog ponašanja (MPI) } \\
\text { - Operation - described by operational indicators (Operational Performance Indicators OPI) / proizvodnje - opisivanje } \\
\text { pokazatelja rada (OPI) } \\
\text { - Environment - described by indicators of the status of environment (Environmental Condition Indicators ECI) } \\
\text { okoliša - opisivanje pokazatelja stanja zaštite okoliša (ECI). } \\
\text { The right implementation of Step } 6 \text { leads to the removal of barriers B5 a, b, c, d. } \\
\text { Pravilna implementacija } 6 . \text { koraka vodi uklanjanju barijera B5 } a, b, c, d \text {. }\end{array}$ \\
\hline \multirow[t]{2}{*}{7.} & $\begin{array}{l}\text { Feedback } \\
\text { Povratne informacije }\end{array}$ \\
\hline & $\begin{array}{l}\text { The objective is to ensure the flow of information on the progress and quality level of the activities of green logistic } \\
\text { Glavni je cilj tog koraka osiguranje protoka informacija o razvoju i kvaliteti razine aktivnosti zelene logistike. }\end{array}$ \\
\hline
\end{tabular}

adoption of cleaner solutions generally implies an increase in costs, which has also been confirmed by our research. As Gonzáles-Benito and Gonzáles-Benito (2006) investigated, companies aiming to decrease the environmental impact of their logistics networks should then look for good trade-offs between environmental impact and costs. The game is, therefore, smartly compromising the two Ps: Planet and Profit (Neto et al., 2009). Lai and Wong (2012), Zhang et al. (2015), Santos et al. (2015) and Shulga et al. (2016) pointed out that green logistics can be seen by manufacturing enterprises not as a 'problem', but more as an 'opportunity'. Due to rising costs of materials and scarcity of resources, such as rare metals, it can be a profitable source for manufacturers to recycle expensive materials from used products.

\section{CONCLUSIONS}

\section{ZAKLJUČAK}

Our research has established a substantial amount of information about possibilities of implementation of green logistics activities in wood processing and forestry SMEs, which would reduce the environmental impact of their products and processes, and improve their performance.

In our study sample (the wood processing and forestry SMEs), the level of understanding, as well as the implementation of green logistics activities were generally low, because $28.8 \%$ of respondents stated that they have not yet encountered any activities of green logistics in their enterprise.

Based on the Friedman and Wilcoxon tests, it may be stated that within the field of green logistics, Slovak wood processing and forestry SMEs are most active in optimizing the transportation routes and making the loading of the transported goods more effective.

With the use of Pareto analysis, it has been established that more than a third of the barriers to implement green logistics, as indicated by the enterprises, are represented by high input costs and lack of support by the government/state.

If small and medium enterprises for wood processing and forestry wish to make their processes more 
ecological, they must first focus on including the initiatives of green logistics into the enterprise strategy, which will improve their implementation in the whole enterprise and will have a positive effect on creating new products and services. It is also important to ensure the orientation on customers, in order to use green knowledge and competencies in satisfying the needs of the current and potential customers, as well as managing and controlling the initiatives of green logistics in accordance with the official statement of the enterprise in the field of green investments.

\section{Acknowledgments - Zahvala}

The authors are grateful for the support of the Scientific Grant Agency of the Ministry of Education, Science, Research, and Sport of the Slovak Republic, and the Slovak Academy of Sciences, Grant No. 1/0010/17, Grant No. 1/0802/16 and Grant APVV-140506 .

\section{REFERENCES}

\section{LITERATURA}

1. Benčiková, D., 2013: Cultural intelligence - fiction or reality?, Management: Science and Education: Slovak Scientific Journal, 2 (2): 5-9.

2. Bikár, M.; Kmet'ko, M., 2015: Global Economy, Monetary Policies and their Impact on Financial Markets. 12th International Scientific Conference on European Financial Systems 2015. Brno, Czech Republik, pp. 37-44.

3. Bjorklund, M.; Martinsen, U.; Abrahamsson, M., 2012: Performance measurements in the greening supply chains. Supply Chain Management an International Journal, 14 (1): 29-39.

http://dx.doi.org/10.1108/13598541211212186.

4. Brandenburg, M.; Rebs, T., 2015: Sustainable supply chain management: a modeling perspective. Annals of Operations Research, 229 (1): 213-252.

http://dx.doi.org/10.1007/s10479-015-1853-1.

5. Sedliačiková, M. et al., 2016: Improving the performance of small and medium wood-processing enterprises. BioResources, 11 (1): 439-450.

https://www.ncsu.edu/bioresources/BioRes 11/BioRes_11_1_439_Sedliacikova_HKVG_Way_Improving Performance Small\%20and\%20Medium Wood Processing 8172.pdf

6. Farahani, P.; Akkermnan, R.; Grunow, M., 2010: Quality, safety and sustainability in food distribution: a review of quantitative operations management approaches and challenges. Operations Research \& Management Science, 32 (4): 863-904.

http://dx.doi.org/10.1007/s00291-010-0223-2.

7. Gonzáles-Benito, J.; Gonzáles-Benito, O., 2006: A review of determinant factors of environmental productivity. Business Strategy and the Environment, 12 (2): 87102. http://dx.doi.org/10.1002/bse.450.

8. Govindan, K.; Khodaverdi, R.; Vafadarnikjoo, A., 2015: Intuitionistic fuzzy based DEMATEL method for developing green practices and performances in a green supply chain. Expert Systems with Application, 42 (20): 72077220 .

http://dx.doi.org/10.1016/j.eswa.2015.04.030.

9. Gunasekaran, A.; Spalanzani, A., 2012: Sustainability of manufacturing and services: investigations for research and applications. International Journal of Production Economics, 140 (1): 35-47. http://dx.doi.org/10.1016/j.ijpe.2011.05.011.

10. Hu, A. H.; Hsu, C. W., 2003: Critical factors for implementing green supply chain management practice: An empirical study of electrical and electronics industries in Taiwan. Management Research Review, 33 (6): 586-608. https://doi.org/10.1108/01409171011050208.

11. Lai, K. H.; Wong, C. W. V., 2012: Green logistics management and performance: Some empirical evidence from Chinese manufacturing exporters. Omega International Journal of Management Science, 40 (3): 267-282. http://dx.doi.org/10.1016/j.omega.2011.07.002.

12. Lesáková, L., 2012: Key factors determining innovation activities in small and medium enterprises in Slovakia. Conference: International Scientific Conference on Knowledge for Market Use - Significance of Knowledge at the Current Phase of Economic Cycle Olomouc, Czech Republic, pp. 270-275.

13. Lipušček, I.; Bohanec, M.; Oblak, L.; Zadnik Stirn, L., 2010: A multi-criteria decision-making model for classifying wood products with respect to their impact on environment. International journal of life cycle assessment, 15 (4): 359-367. http://dx.doi.org/10.1007/s11367-010-0157-6.

14. Lun, Y. H. V.; Lai, K. H.; Wong, C. W. Y.; Cheng, T. C. E., 2015: Greening propensity and performance implications for logistics service providers. Transportation Research Part E - logistics and Transportation Review 71: 50-62. http://dx.doi.org/10.1016/j.tre.2014.10.002.

15. Minárová, M., 2014: Role of learning organization in building consumer confidence. E\&M Economics and Management, 1 (XVII): 62-72.

16. Neto, J. Q. F.; Walther, G.; Bloemhof, J.; Bloemhof, J.; van Nunen, J.; Spengler, T., 2009: A methodology for assessing eco-efficiency in logistic networks. European Journal of Operational Research, 193 (3): 647-914. http://dx.doi.org/10.1016/j.ejor.2007.06.056.

17. Nováková, R., 2003: An Important Role of Buyers and Suppliers Relations in the Economy of Smail and Medium Enterprises. Annals of Warsaw Agricultural University: Forestry and Wood Technology. Special No. II: 90-93.

18. Nováková, R.; Kusý, O., 2010: Environmentalism and its impact on quality management, Upravlenie ekonomikoj: metody, modeli, technologii. Tom 2: X Meždunarodnaja konferencija s elementami naučnoj školy dlja molodeži. 2010, Ufa. UGATU, pp. 212-215.

19. Ojurović, R.; Moro, M.; Šegotić, K.; Grladinović, T.; Oblak, L., 2013: Analysis of the investment in wood processing and furniture manufacturing entities by key factors of competitiveness. Drvna industrija, 64 (2): 131137. http://dx.doi.org/10.5552/drvind.2013.1235.

20. Santos, J. D.; Borloton, K. M.; Chiroli, D. M. D.; Oiko, O. T., 2015: Green logistics: conceptualization and directions for practice, Revista Eletronica em Gestao Educacao e Technologia Ambiental, 19 (2): 314-331.

21. Seroka-Stolka, O., 2014: The development of green logistics for implementation sustainable development strategy in companies, Procedia - Social and Behavioral Sciences, 151: 302-309. http://dx.doi.org/10.1016/j.sbspro.2014.10.028.

22. Sheu, J. B.; Chou, Y. H.; Hu, C. C., 2005: An integrated logistics operational model for green-supply chain management, Transportation Research Part E - logistics and Transportation Review, 41 (4): 287-313. http://dx.doi.org/10.1016/j.tre.2004.07.001. 
23. Shulga, G.; Neiberte, B.; Verovkins, A.; Jaunslavietis, J.; Shakels, V.; Vitolina, S.; Sedliačik, J., 2016: Eco-friendly constituents for making wood-polymer composites. Key Engineering Materials, 688 (1): 122-130.

http://dx.doi.org/10.4028/www.scientific.net/ KEM.688.122.

24. Tognetti, A.; Grosse-Ruyken, P. T.; Wagner, S. M., 2015: Green supply chain network optimalization and the trade-off between environmental and economic objectives. International Journal of Production Economics 170: 385-392. http://dx.doi.org/10.1016/j.ijpe.2015.05.012.

25. Vavrová, K., 2014: Effect of subsidies non-investment provided for profit (tax base) company. Conference: International Conference on Current Problems of the Corporate Sector. Bratislava, Slovakia, pp. 532-538.
26. Zhang, S. Z.; Lee, C. K. M.; Chan, H. K.; Choy, K. L.; Wu, Z., 2015: Swarm intelligence applied in green logistics: A literature review. Engineering Applications of Artificial Intelligence 37: 154-169.

http://dx.doi.org/10.1016/j.engappai.2014.09.007.

\section{Corresponding address:}

Assoc. Prof. MARIANA SEDLIAČIKOVÁ, Ph. D.

Faculty of Wood Sciences and Technology

Technical University in Zvolen

T. G. Masaryka 24

96053 Zvolen, SLOVAKIA

e-mail: sedliacikova@tuzvo.sk 